\title{
Spring distribution and density of minke whale Balaenoptera acutorostrata along an offshore bank in the central North Sea
}

\author{
Marijke N. de Boer* \\ Wageningen IMARES, Institute for Marine Resources and Ecosystem Studies, Postbus 167, 1790 AD Den Burg, \\ The Netherlands
}

\begin{abstract}
Minke whales were recorded in the central North Sea in an area characterised by frontal features and high productivity northeast of the Dogger Bank $\left(4677 \mathrm{~km}^{2}\right)$. Survey efforts were carried out from 28 March to 2 July 2007, at a finer scale than in earlier studies in the region, using 2 vessels as platforms of opportunity and a dedicated line-transect survey vessel following distance sampling methods. The high density of whales indicated that this offshore bank slope is an important spring habitat for minke whales in the North Sea. In total, 77 sightings of minke whales comprising 130 individuals were recorded. The peak density of minke whales was estimated to be 0.029 whales $\mathrm{km}^{-2}$ (minimum estimate, 95\% CI: 0.012 to 0.070) in May. During peak abundance, the minke whales temporarily congregated in the area, suggesting that the whales were taking advantage of the local spring abundance of sandeels. The density found was higher than previous studies have suggested for the central North Sea. The results correspond to recent observations of minke whale redistribution within the North Sea, and these may be related to a decline in sandeel availability elsewhere in the North Sea. Offshore banks that aggregate prey may therefore become increasingly important feeding habitats for minke whales and other top predators in the North Sea. The observed habitat preference of minke whales along this offshore bank appeared to be similar to that observed in coastal areas, and this suggests some degree of generality regarding the preference for this type of habitat.
\end{abstract}

KEY WORDS: Minke whale $\cdot$ Distribution $\cdot$ Density $\cdot$ Relative abundance $\cdot$ Offshore bank $\cdot$ Platform of opportunity $\cdot$ Line-transect survey $\cdot$ Central North Sea

Resale or republication not permitted without written consent of the publisher

\section{INTRODUCTION}

The northern minke whale Balaenoptera acutorostrata occurs widely in the northeast Atlantic and the North Sea, although this species is less common in the southern North Sea (Evans et al. 2003, Reid et al. 2003). In the northern North Sea, minke whales are mainly seen from April to October (Northridge et al. 1995, MacLeod et al. 2007, Robinson et al. 2007, Weir et al. 2007) although they can be seen year-round (Macleod et al. 2004). Most studies of North Atlantic minke whales have been carried out at either a large spatial scale (Hammond et al. 2002, Skaug et al. 2004) or at fine scale targeting coastal waters (Naud et al. 2003, Macleod et al. 2004, Robinson et al. 2007, 2009, Tetley et al. 2008). There appears to be a general pattern of minke whales moving into coastal areas in the late summer, but overall there is little knowledge regarding the seasonal distribution of minke whales (and cetaceans in general) in offshore habitats (MacLeod et al. 2007). One such offshore habitat is the Dogger Bank in the central North Sea, where Atlantic waters from the north meet and mix with waters from the English Channel (Pingree \& Griffiths 1978, Van Haren \& Joordens 1990). Most of the water column remains mixed throughout the year because of tidal mixing, while from May until September stratification occurs in deeper waters around this shallow sand bank (Pingree \& Griffiths 1978). Relatively high primary production values have been reported in summer (Riegman \& Colijn 1991), although this productivity on a small scale is patchy due to the complex hydrodynamics and the irregular occurrence of wind mixing. 
The present study was conducted between 29 March and 2 July along the northeastern slopes of the Dogger Bank and partially overlapped with recently announced/proposed special areas of conservation (SACs) according to the Habitats Directive of the European Union (Annex I: sandbank habitat; Lindeboom et al. 2005, Diesing et al. 2009). The bank offers a suitable sandeel habitat, and studies on fish, seabirds, and to a lesser degree cetaceans (e.g. Knijn et al. 1993, Stone et al. 1995, Evans et al. 2003) show that it has a high biodiversity. Minke whales have mainly been reported to the north and west of the Dogger Bank with only few sightings to the northeast. Other cetaceans, such as the harbour porpoise Phocoena phocoena and white-beaked dolphin Lagenorhynchus albirostris, are more common (Hammond et al. 2002, Evans et al. 2003, Reid et al. 2003, Van der Meij \& Camphuysen 2006, SCANS-II 2008, Gilles et al. 2009). According to the EU Habitats and Species Directive, the minke whale is not an Annex-II-listed species and therefore the proposed Dogger Bank SAC may only include the harbour porpoise under this Annex.

The distribution and abundance of minke whales on feeding grounds will ultimately depend on the distribution of their prey and underlying primary production. Factors such as water depth, seabed sediment, fronts, and tides also influence the distribution and abundance of minke whales (Naud et al. 2003, Macleod et al. 2004, Johnston et al. 2005, Tetley et al. 2008, Robinson et al. 2009). The species also shows intra- and inter-annual variations in fine-scale distribution (Robinson et al. 2009), which highlights the need for longterm research effort in SACs.

The objective of the present study was to verify the distribution and density of minke whales and other cetaceans and to contribute to the understanding of the cetacean ecology along this offshore bank. Here we report on a complementary approach during a geophysical survey involving 2 research vessels used as platforms of opportunity (PO) and 1 dedicated linetransect (LT) survey vessel following distance sampling methods. The PO survey was conducted over a longer time span, and the results are used to (1) assess the cetacean community, (2) determine any observed temporal variability in occurrence, and (3) highlight the advantage of such surveys. The LT survey results are used to estimate the density of minke whales.

\section{MATERIALS AND METHODS}

Study site. The study site $\left(4677 \mathrm{~km}^{2}\right)$ ranged from $2^{\circ} 54^{\prime}$ to $4^{\circ} 33^{\prime} \mathrm{E}$ and from $55^{\circ} 30^{\prime}$ to $56^{\circ} 18^{\prime} \mathrm{N}$ in an area northeast of the Dogger Bank stretching out over British, Dutch, Danish, and German waters (Fig. 1). The waters ranged in depth from $23 \mathrm{~m}$ (SE) to $70 \mathrm{~m}$ (NW) and ran from tidally mixed to temperature-stratified. A survey stratum of $848.6 \mathrm{~km}^{2}$ was covered by both dedicated and opportunistic survey effort in German waters (Fig. 1).

Data collection. Observations were conducted during a geophysical seismic survey (28 March to 2 July 2007) involving 2 PO vessels: the $91 \mathrm{~m} \mathrm{RV}$ 'Atlantic Explorer' (PO1) carrying out a geophysical survey and the $46 \mathrm{~m}$ support motor vessel (MV) 'Thor Provider' (PO2, 31 March to 13 June). In addition, the $38 \mathrm{~m} \mathrm{MV}$ 'Andfjord' carried out a dedicated LT survey (23 April to 17 May). PO1 was sailing predetermined parallel survey transects and was accompanied by PO2, which sailed parallel and ahead of PO1. The PO vessels were in frequent communication regarding sightings and are regarded as one ('tandem') platform. The LT vessel was surveying at distances of $\geq 20 \mathrm{~km}$ away from the PO vessels and followed predetermined line transects placed randomly in a zigzag pattern in the central (German) part of the survey area. The vessels travelled at 4.5 knots (PO) and 6 knots (LT).

Experienced observers searched for cetaceans from the bridge deck (heights: PO2/LT: 6.25 to $7.0 \mathrm{~m}$ and PO1: 10.5 to $13.5 \mathrm{~m})$. Dedicated watches were conducted during daylight with one observer on watch. After mid-June one observer remained onboard PO1, reducing the amount of effort due to planned breaks. Observers scanned with the naked eye and used binoculars $(7 \times 50$ and $8 \times 42)$ for identification and groupsize estimations. Standard recording forms were used (JNCC 2004). When a sighting was made, the vessel continued on the track-line. The radial sighting distance was determined using reticule binoculars or person-specific range sticks. The bearing to animal(s) and heading were determined by ship's compass or using an angle-board (LT vessel). Other sightings data included water depth (depth sounder or electronic sea chart), species identification (definite, probable, or possible), calf/juvenile presence, group-size (maximum, minimum, or best), composition, and behaviour.

Data analysis. Data collected in slight Beaufort Sea States (BSS) 0 to 4 , good visibility $(>1 \mathrm{~km}$ ) and low swells $(<4 \mathrm{~m})$ were used for density calculations. Duplicate sightings made from the PO vessels were verified (using time, position, composition, heading, and PO-communication data) and excluded. Both definite identification and probable identification of species were used.

Relative abundance. The relative abundance was measured as the number of sightings $100 \mathrm{~km}^{-1}$. A grid with a resolution of $10 \times 10 \mathrm{~nm}$ was created, and cells with a survey effort $<10 \mathrm{~km}$ were excluded. The latitude and longitude were assigned to the centre of each grid cell when determining the mean water depth.

Density and responsive movement. Minke whale density (whales $\mathrm{km}^{-2}$ ) was estimated from LT data fol- 


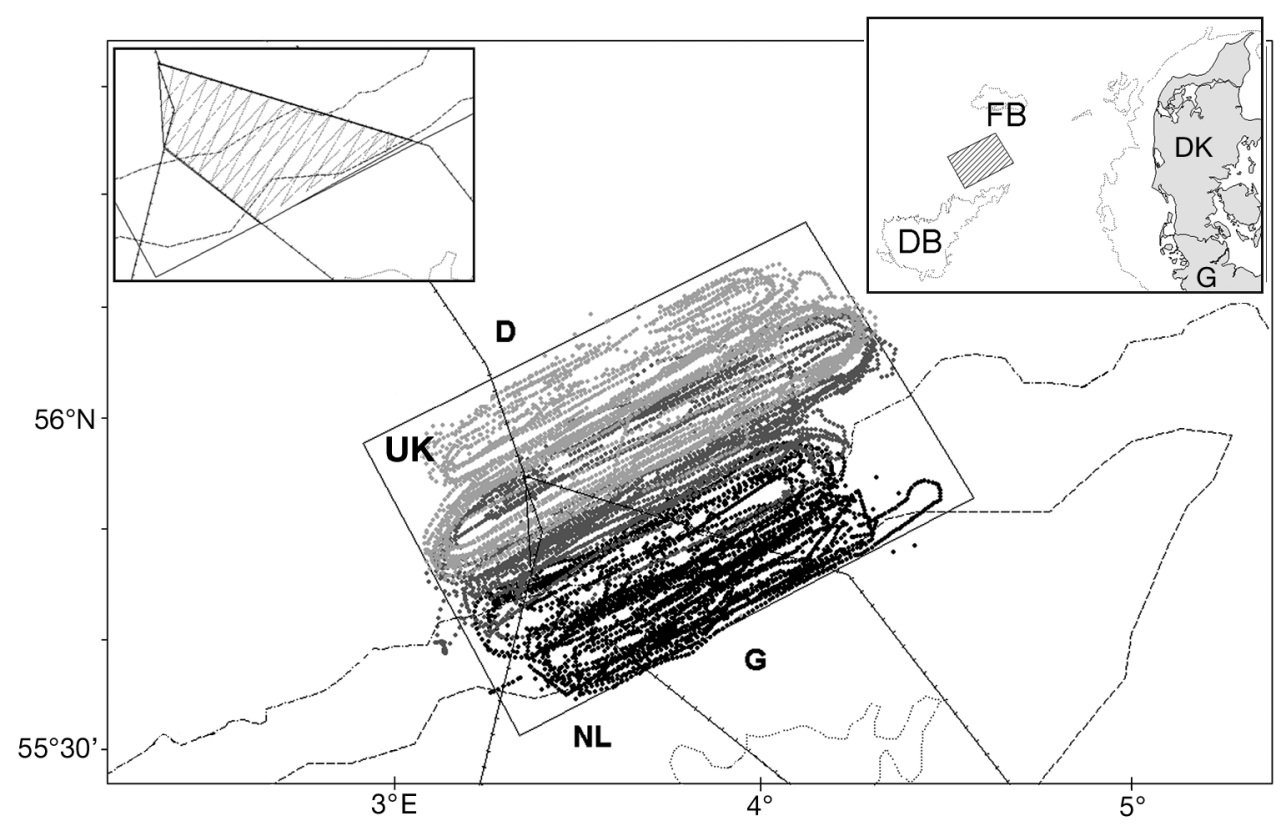

Fig. 1. The central North Sea study area (rectangle) was surveyed by platforms of opportunity (PO) vessels with effort in April (in black), May (in dark grey) and June (in light grey). Line transects are displayed in the left inset image (dotted zigzag lines), where one set was covered 3 times and the other 2 times. The Dogger Bank (DB) and Fisher Bank (FB) are shown in the right inset image. International exclusive economic zone (EEZ) waters (Denmark [D], United Kingdom [UK], The Netherlands [NL], and Germany [G]) and depth contours are shown: $50 \mathrm{~m}$ (dash-dot line), $40 \mathrm{~m}$ (dashed line) and $30 \mathrm{~m}$ (dotted line)

lowing both conventional (CDS) and multiple covariate distance sampling (MCDS) approaches (Buckland et al. 2001, Marques \& Buckland 2003) using Distance 4.1 (Research Unit for Wildlife Population Assessment). Essentially, the program fits a detection function to the distribution of perpendicular distances and this function is used to estimate the effective strip half-width (ESW). The density (whales $\mathrm{km}^{-2}$ ) is given as:

$$
D=\frac{n \cdot E(S)}{2 L \cdot E S W \cdot g(0)}
$$

Where $\mathrm{n}$ is the number of detections, $L$ is the length of transect $(\mathrm{km}), E(S)$ is the mean group size, and $g(0)$ is the detection probability on the track-line. MCDS allows for the inclusion of environmental covariates in the estimation of detection probability. It is expected that the detection probability is positively correlated with group size but negatively correlated with the sea state (e.g. Buckland et al. 2001). The estimates of density generated here are based on a number of assumptions, including that the probability of detecting minke whales on the track-line, $g(0)=1$, i.e. every animal on the track-line is detected. Another assumption of the line-transect methodology is that animals do not respond to the approaching survey vessel before detection. This was investigated by using a vector component of the whale's velocity away from the vessels (i.e. the cosine of the difference between bearing and heading; de Boer et al. 2008).

\section{RESULTS}

\section{Survey effort and summary of sightings}

A total of $9902 \mathrm{~km}$ PO effort was completed during $96 \mathrm{~d}$ (Table 1). The southern, middle, and northern sectors of the study site were surveyed in April, May, and June, respectively (Fig. 1). 103 sightings were made, totalling 281 animals involving 6 species (Table 2). Some PO sightings remained unidentified $(12.5 \%$; Table 2). The LT survey covered $1452 \mathrm{~km}$ planned effort (Table 1) from 23 April to 17 May; 31 cetacean sightings were made, totalling 112 animals (Table 2).

\section{Minke whale density}

To reduce bias in mean group size estimates due to the potential of a positive relationship between group size and perpendicular distance $(x)$, exploratory analysis (regression of group size versus detection probability) was carried out. The detections were independent of group size and therefore mean group size was used. Because of small sample size $(n=22)$, models with single covariates were considered. Akaike's information criterion (AIC) was used, and the best fitting model was the half-normal key function with cosine series expansion (Fig. 2). The sea state was selected as a covariate in the analysis model. The 
density estimate was 0.029 whales $\mathrm{km}^{-2}(95 \% \mathrm{CI}$ : 0.012 to $0.070,0.51 \mathrm{CV})$. The vector component of the whale's velocity was explored, and this suggested no responsive movement of the whales prior to detection.

Table 1. Extent of visual effort for platforms of opportunity (PO) and linetransect (LT) vessels, including the percentage of survey effort in Beaufort sea state $\leq 4(\%$ BSS $)$

\begin{tabular}{|c|c|c|c|c|}
\hline $\begin{array}{l}\text { Research } \\
\text { vessel }\end{array}$ & $\begin{array}{l}\text { Survey } \\
\text { period }\end{array}$ & $\begin{array}{c}\text { Hours of } \\
\text { effort }\end{array}$ & $\begin{array}{c}\text { Survey } \\
\text { effort }(\mathrm{km})\end{array}$ & $\%$ BSS \\
\hline PO vessels & 28 March-2 July 2008 & 951 & 9901.7 & 81 \\
\hline LT vessel & 23 April-17 May 2008 & 318 & 1452 & 99 \\
\hline All vessels & 28 March-2 July 2008 & 1269 & 11353.7 & 83 \\
\hline
\end{tabular}

Table 2. Information on sightings and individuals (in parentheses). The relative abundance (N/L, the number of sightings $100 \mathrm{~km}^{-1}$ ) for different species observed from PO and LT vessels are shown for all weeks (Weeks 1 to 14) and for 24 April to 21 May (Weeks 5 to 8)

\begin{tabular}{|c|c|c|c|c|c|}
\hline Species & $\mathrm{PO}$ & LT & $\begin{array}{l}\text { N/L-PO } \\
\text { (Weeks } \\
1 \text { to } 14 \text { ) }\end{array}$ & $\begin{array}{l}\text { N/L-PO } \\
\text { (Weeks } \\
5 \text { to } 8 \text { ) }\end{array}$ & $\begin{array}{c}\text { N/L-LT } \\
\text { (Weeks } \\
5 \text { to } 8 \text { ) }\end{array}$ \\
\hline Minke whale & $55(70)$ & $22(60)$ & 0.56 & 1.77 & 1.52 \\
\hline Humpback whale & $1(1)$ & 0 & 0.01 & 0.04 & 0 \\
\hline $\begin{array}{l}\text { Atlantic white-sided } \\
\text { dolphin }\end{array}$ & $8(78)$ & $2(25)$ & 0.08 & 0.14 & 0.14 \\
\hline White-beaked dolphin & $5(37)$ & 0 & 0.05 & 0.07 & 0 \\
\hline $\begin{array}{l}\text { Atlantic white-sided/ } \\
\text { white-beaked dolphin }\end{array}$ & $1(4)$ & $1(20)$ & 0.01 & 0.04 & 0.07 \\
\hline Bottlenose dolphin & $1(1)$ & 0 & 0.01 & 0 & 0 \\
\hline Harbour porpoise & $15(28)$ & $6(7)$ & $\begin{array}{l}0.15 \\
0.45^{\mathrm{a}}\end{array}$ & $\begin{array}{l}0.25 \\
0.45^{\mathrm{a}}\end{array}$ & $\begin{array}{l}0.41 \\
1.27^{\mathrm{a}}\end{array}$ \\
\hline Unidentified dolphin & $9(50)$ & 0 & 0.09 & 0.07 & 0 \\
\hline Unidentified whale & $6(8)$ & 0 & 0.06 & 0.18 & 0 \\
\hline Unidentified cetacean & $2(4)$ & 0 & 0.02 & 0.04 & 0 \\
\hline Totals & $103(281)$ & $31(112)$ & 1.04 & 2.58 & 2.13 \\
\hline
\end{tabular}

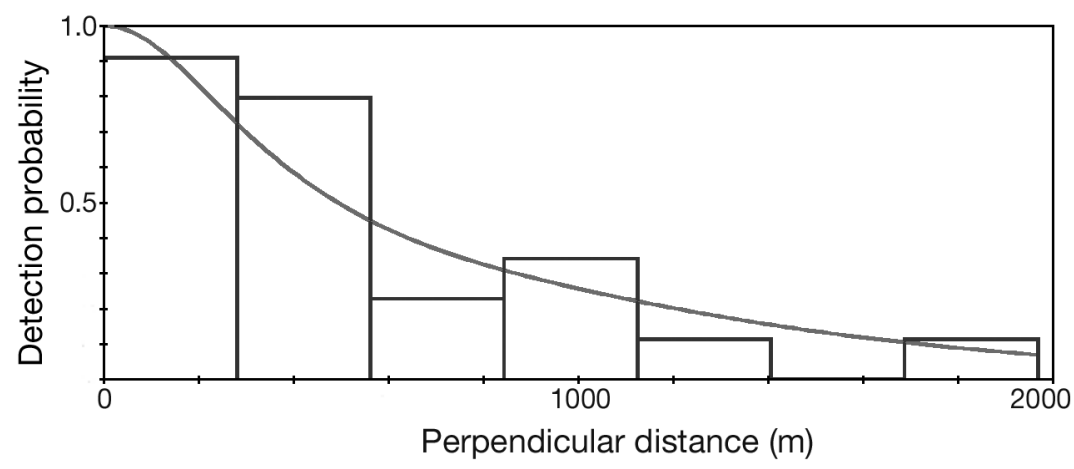

Fig. 2. Balaenoptera acutorostrata. Perpendicular sighting distances, detection probability, and fitted detection function for minke whales in German waters of the study area, central North Sea

\section{PO versus LT survey}

The first minke whale sightings were made on 26 April (LT) and 30 April (PO). The whales were relatively abundant for 4 wk (Weeks 5 to 8 of the survey: 24 April to 21 May; Fig. 3). One juvenile was sighted. The LT effort was restricted by inclement weather conditions and finished on 17 May. During Week 8, the whales were observed in deeper waters. The PO surveys offered enough temporal coverage to show that whale numbers were nearing zero from Week 9 (Fig. 3). The mean water depth of minke sightings (PO) was < $50 \mathrm{~m}$ (Weeks 5 to 6 ) and $>55 \mathrm{~m}$ (Weeks 7 to 8 ), whilst this measured $<50 \mathrm{~m}$ throughout the LT survey. The mean group sizes measured for minke whales were $1.26(\mathrm{PO}[ \pm 0.7 \mathrm{SD}$ ]; $\mathrm{n}=50$, Weeks 5 to 8 ) and 2.7 (LT [ $\pm 3.9 \mathrm{SD}$ ]; $\mathrm{n}=$ 22). The latter was affected by a large group (20 whales); however, without this sighting the mean group size remained high (1.9). The average sighting distance (LT) was short (752 m) and explains why all animals were identified to species. The relative abundance peaked during Week 6 (PO) and Week 7 (LT). Overall (Weeks 5 to 8) the PO survey measured the highest relative abundance (1.77 whales $100 \mathrm{~km}^{-1}$; Table 2).

\section{Movement and foraging behaviour}

Three types of foraging behaviour were observed $(\mathrm{PO}+\mathrm{LT})$ : (1) whales making quick directional changes, (2) association with seabirds, and (3) lunge feeding. During Week 5, the whales were observed in the southwestern sector (Fig. 4A). In Week 6, the majority of whales had spread northeast and were congregating along the $50 \mathrm{~m}$ depth contour. In Week 7, the whales had moved further northeast, and by Week 8 the distribution was more spread out (Fig. 4C). A high relative abundance (2.04 whales $100 \mathrm{~km}^{-1}$ ) was measured in water depths ranging between 50 and $59 \mathrm{~m}$ (Fig. 4F), and this was slightly lower (1.75) in depths ranging between 40 and $47 \mathrm{~m}$ (Fig. 4F). A high relative abundance (>6) was measured (at depth $69 \mathrm{~m}$ ), but this was based on only one sighting. The 


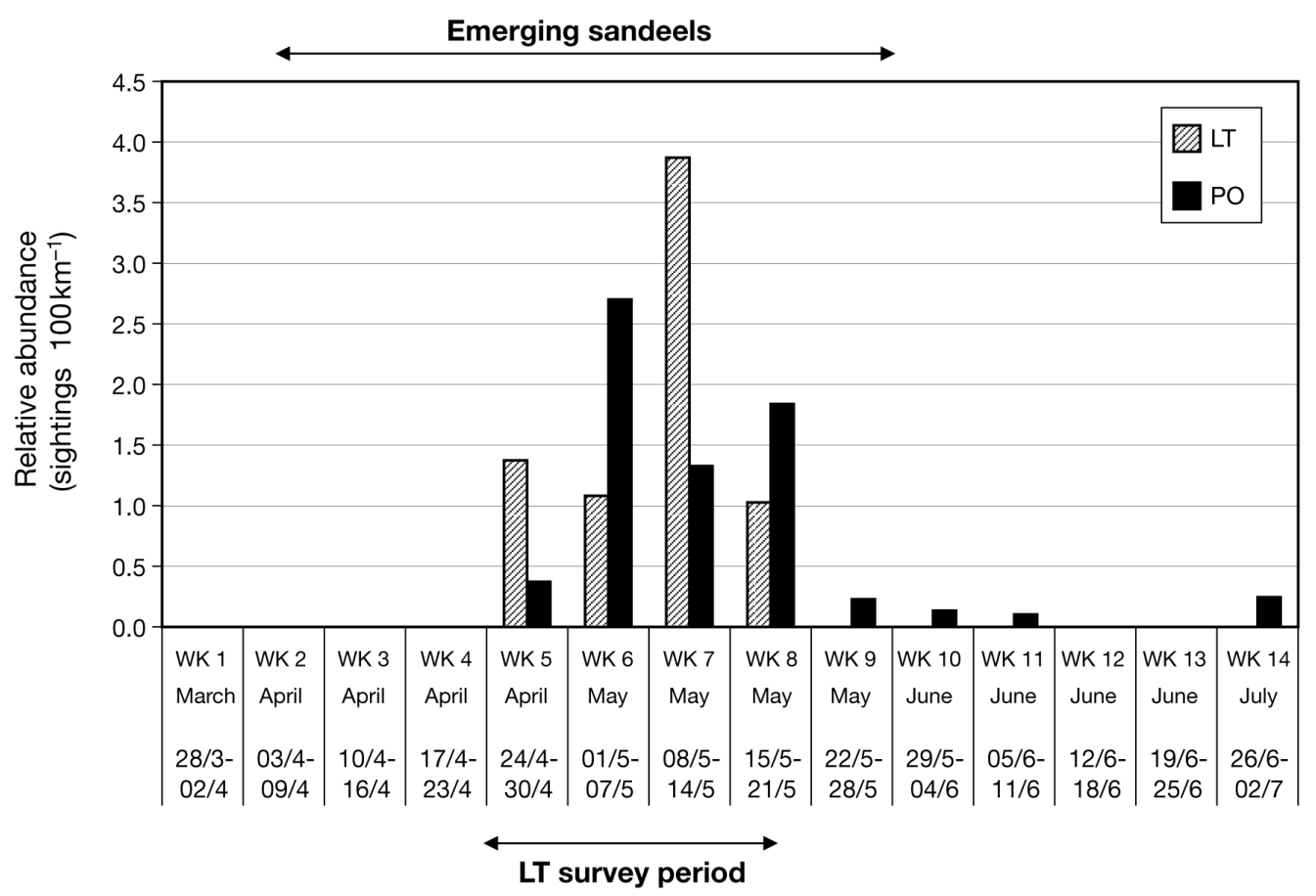

Fig. 3. Balaenoptera acutorostrata. Relative weekly (WK) abundance of minke whales (whales $100 \mathrm{~km}^{-1}$ ) from platform of opportunity (PO) and line-transect (LT) surveys

latitudes of the sighting positions were plotted and confirmed a northerly movement of the whales $(\mathrm{p}<0.05$, $\mathrm{r}^{2}=0.422$, linear regression). The PO coverage varied over a long time; it is unknown whether the whales remained present in the southern sector, but given the northerly movement this seems unlikely.

\section{DISCUSSION}

\section{Minke whales}

The estimated minke whale density in April-May was 0.029 whales $\mathrm{km}^{-2}$ (95\% CI: 0.012 to $0.070,0.51$ $\mathrm{CV})$, which is higher than the SCANS densities reported in July (Block G [SCANS-I 1994]: south-central North Sea 0.0088 whales $\mathrm{km}^{-2}, 0.70 \mathrm{CV}_{\text {; }}$ Block U [SCANS-II, 2005]: south-central North Sea 0.022 whales $\mathrm{km}^{-2}, \mathrm{CV}$ 0.69) and corresponds to the density in Block V in July 2005 (Block V [SCANS-II]: northcentral North Sea 0.028 whales $\mathrm{km}^{-2}$, CV 0.45; Hammond et al. 2002, SCANS-II 2008). Other studies report on comparable densities between 0.002 and 0.078 whales $\mathrm{km}^{-2}$ in the northeast Atlantic (Skaug et al. 2004), whereas densities off Alaska (0.002 to 0.017 whales $\mathrm{km}^{-2}$; Zerbini et al. 2006) and California (0.00072 whales $\mathrm{km}^{-2}$; Barlow \& Forney 2007) were lower.

The group size of minke whales (2.7: LT) was high compared to SCANS (Block G: 1.33; Block U: 1.0;
Block V: 1.05; Hammond et al. 2002, SCANS-II 2008). The SCANS relative abundances for minke whales (Block G: 0.33 whales $100 \mathrm{~km}^{-1}$; Block U: 0.58; Hammond et al. 1995; and Block V: 0.69; SCANS-II 2008) are lower than the LT survey (1.52 whales $\left.100 \mathrm{~km}^{-1}, 0.21 \mathrm{CV}\right)$ whereas the PO survey revealed a corresponding abundance $\left(0.56\right.$ whales $\left.100 \mathrm{~km}^{-1}\right)$ compared to Block U, although during the 'peak' period this was much higher (Weeks 5 to 8: 1.77 whales $100 \mathrm{~km}^{-1}$ ). The PO coverage of the study area varied over time, and whale movements may have impacted the observed relative abundances. High local relative abundances for minke whales have been reported off Mull, Scotland (2.1 whales $100 \mathrm{~km}^{-1}$ in spring; Macleod et al. 2004) and off the Moray Firth ( 0.7 to 3.9 whales $100 \mathrm{~km}^{-1}$ in summer; Robinson et al. 2007), suggesting that minke whales may temporarily congregate on favoured feeding grounds.

\section{Potential sources of bias}

The lack of a correction factor for $g(0)$ probably causes substantial bias in minke whale densities (e.g. Schweder et al. 1999, Skaug et al. 2004). Skaug \& Schweder (1999) estimated that 56 to $68 \%$ of minke whales were missed during surveys in the north Atlantic. SCANS implemented methods that allow for the estimation of a correction factor (SCANS-I: $g(0)=0.82$ to 1.0; Hammond et al. 1995). The whale density esti- 

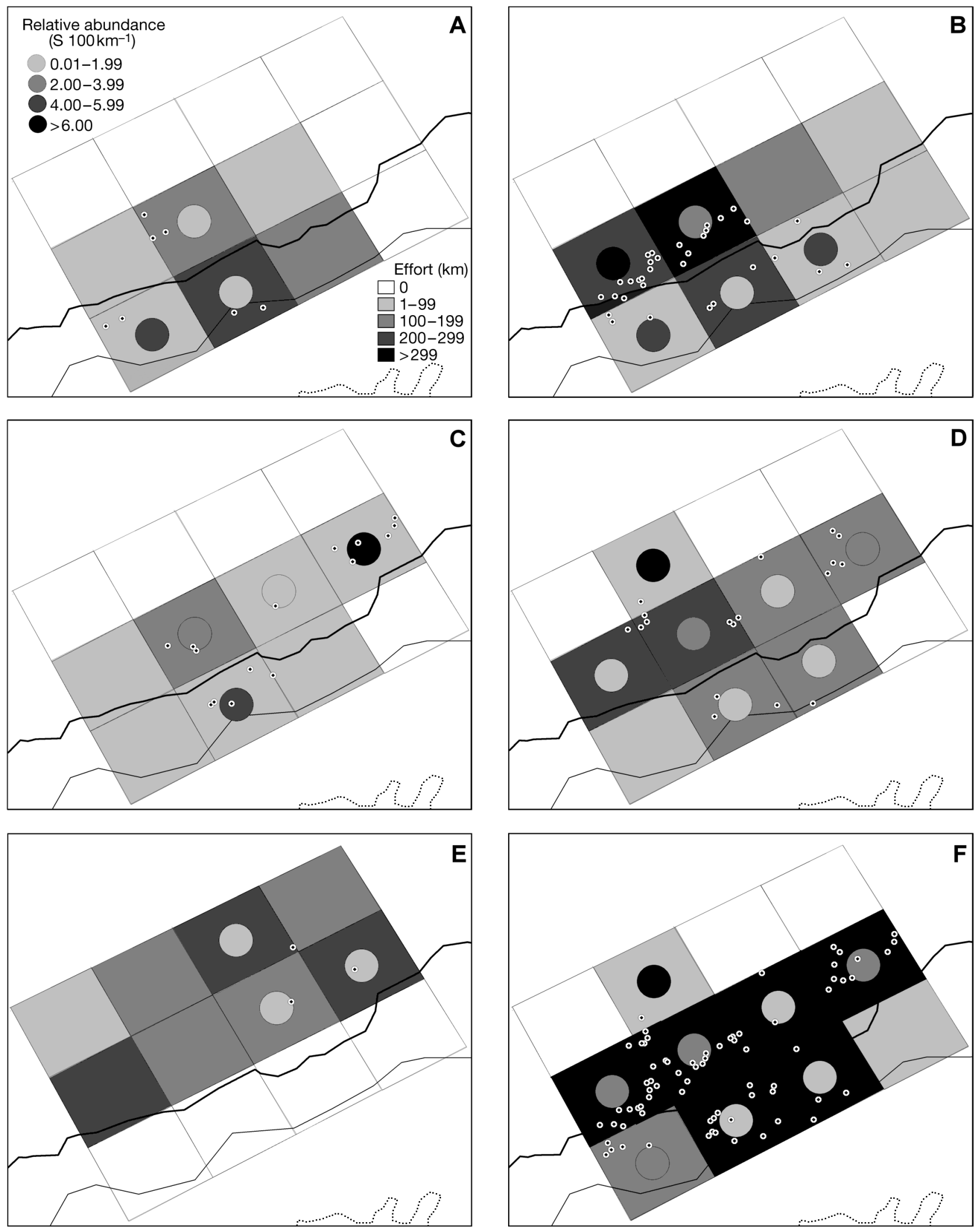

Fig. 4. Balaenoptera acutorostrata. Distribution of effort $(\mathrm{km})$ and spatial distribution of relative abundance $\left(\right.$ sightings $\left.100 \mathrm{~km}^{-1}\right)$ from all vessels during (A) Week 5, (B) Week 6, (C) Week 7, (D) Week 8, (E) Weeks 9 \& 10 (PO only), and (F) Weeks 5 to 8 (PO + LT). Effort is indicated by shaded blocks; relative abundance is indicated by shaded circles; and sightings are plotted as open dots. Depth contours: $50 \mathrm{~m}$ (thick line), $40 \mathrm{~m}$ (thin line) and $30 \mathrm{~m}$ (dotted line) 
mated here must be regarded as a minimum because correction factors could not be calculated. Furthermore, LT surveys generally have 2 observers on watch whilst this survey used 1 . The effect of excluding the covariate for sea state resulted in a negative bias of $17.8 \%$ in the density estimate, and similar patterns have been shown in other studies (Schweder et al.1999, Skaug et al. 2004, Palka 2005). It was not possible to assess the effect of relatively slow survey speed or the problems of replicating transect lines. However, this may have caused a positive bias in the density estimate. The differences in whale density may be a result of timing (summer versus spring). Minke whale surfacing rates in western Scotland have been shown to vary as a result of different foraging strategies for different prey, with slightly higher rates measured in May compared to those in June and July (Stockin et al. 2001). It is likely that foraging minke whales have short surfacing intervals, which may cause a positive bias (Stockin et al. 2001).

\section{Offshore bank}

The present study area lies along the slopes of the Dogger Bank and includes a delicate transition zone between tidally mixed and stratified waters characterised by relatively high primary production values during summer (Riegman \& Colijn 1991) and in May (Van Haren \& Joordens 1990). The latter is the result of a front that causes a subtidal current predominantly directed along the isobath and enhanced vertical mixing (Van Haren \& Joordens 1990). Other frontal zones in the region are the Spurn and Flamborough Head fronts (Pingree \& Griffiths 1978), which lie to the west. Frontal systems can be regarded as biological 'hot spots' where within short distances significant changes can be observed in the pelagic food web regarding productivity, structure, and diversity (Nielsen Gissel \& Munk 1998).

In May, high numbers of sandeels Ammodytes sp. were reported in the study area by Danish fishermen and PO1 crew. Stomach contents studies (Folkow et al. 2000, Olsen \& Holst 2001, Pierce et al. 2004) have shown that the lesser sandeel $A$. marinus is a preferred prey for North Sea minke whales. Sandeels are a schooling fish that emerge from the sandy substrata during April-May in which they over-winter. They emerge during daylight to forage on calanoid copepods (Macer 1966, Winslade 1974). Highest monthly landings of sandeels were reported in the area in May-June 2001 to 2008 (Boulcott et al. 2006, ICES 2008a). The study area also boarders onto the Fischer Bank, where the concentration of sandeel larvae peaked near a front in May (Nielsen Gissel \& Munk 1998). A seasonal distribution of minke whales over sandeel habitat was reported off Scotland during June
(Macleod et al. 2004). Similar observations of pelagic daytime feeding behaviour on sandeels were found in the northern North Sea (Olsen \& Holst 2001) and along offshore banks in Greenland (Laidre et al. 2009).

The minke whales were associated with the $50 \mathrm{~m}$ depth contour (Fig. 4). It is hypothesised that the slopes of this offshore bank were acting as a temporary congregation area when considerable primary production over suitable sandy sediments resulted in an increased availability of sandeels to foraging minke whales. From late May the feeding conditions for minke whales were no longer optimal for unknown reasons, although it is likely that this temporary congregation site probably extended beyond the study area. The habitat preferences of minke whales along this offshore bank appeared to be similar to those previously observed in coastal areas, in particular the association with the $50 \mathrm{~m}$ isobath, gravel/sand sediments and steep slopes (Macleod et al. 2004, Robinson et al. 2009). This suggests some degree of generality regarding the habitat preferences of minke whales in the north Atlantic.

Early spring plankton at the Dogger Bank is patchily distributed, and sandeels only emerge from the seabed when feeding conditions are optimal (Van der Kooij et al. 2008). Because sandeels depend on such a specific habitat and form clusters of schools, it makes them vulnerable to local depletion (Mackinson 2007).

\section{Cetacean diversity}

The species diversity recorded along this offshore bank was high: 6 cetacean (Table 2, Fig. 5) and 2 seal species. The PO data are potentially influenced by unknown reactions of each species to sound produced during the PO1 operations. The porpoise relative abundance from the PO survey was lower than the LT survey (PO: 0.45 and LT: 1.27 porpoises $100 \mathrm{~km}^{-1}$, April-May), although this was based on low sample size. This was also much lower than measured in the central North Sea in July (Block G: 3.53, Block U: 4.85 porpoises $100 \mathrm{~km}^{-1}$; Hammond et al. 2002, SCANS-II 2008) and in May (13.00 porpoises $100 \mathrm{~km}^{-1}$, Gilles et al. 2009). The harbour porpoise is common in the North Sea and occurs year-round in the southern North Sea (Camphuysen 2004). The porpoise has also been reported at the Dogger Bank in winter (Todd et al. 2009). Although porpoises are notoriously difficult to observe, we expected to see more porpoises, particularly since sandeels may be important prey (Santos et al. 2004).

White-beaked dolphins are common in the central North Sea (Evans et al. 2003, Reid et al. 2003), but Atlantic white-sided dolphins Lagenorhynchus acutus dominated north of the $50 \mathrm{~m}$ depth contour. Other sightings included a (probable) bottlenose dolphin 
Tursiops truncatus and humpback whale Megaptera novaeangliae (3 May). Interestingly, 1 wk later a humpback whale was reported off the Dutch coast (10 to 13 May 2007; Camphuysen 2007).

\section{Redistribution of minke whales}

In the North Sea the timing of various plankton groups do not seem to respond to ocean warming synchronously, resulting in predator-prey mismatches that resonate to higher trophic levels, such as fish, seabirds, and marine mammals (Edwards \& Richardson 2004). SCANS-I showed that minke whales were more abundant in the northwest North Sea (north of $55^{\circ} \mathrm{N}$ and west of $4^{\circ} \mathrm{E}$; Hammond et al. 2002), and the SCANS-II density surface models predicted highest concentrations of animals in the central North Sea (west of the study area), off Norway, northeastern Scotland, southwestern England, and southern Ireland (SCANS-II 2008). Minke whales were also concentrating further south in summer than previously recorded in the northwest North Sea (54 to $58^{\circ} 30^{\prime} \mathrm{N}, 2^{\circ} \mathrm{E}$; Camphuysen et al. 2006). The results presented here corroborate the other observations of minke whale redistribution within the North Sea. The observed southward change in minke whale distribution is yet unexplained, but may be related to environmental factors such as a decline in prey availability, most likely that of sandeels, elsewhere in the North Sea (ICES 2008b).

\section{PO versus LT survey}

PO vessels provide a low-cost tool for cetacean research and provide opportunities to survey otherwise inaccessible offshore habitats. The combination of different methodologies to solve problems associated with the choice of a single method has proven to be effective, e.g. aerial and boat-based surveys, acoustic and visual surveys, and aerial and PO surveys (Hammond et al. 2002, Certain et al. 2008, SCANS-II 2008). Unique for this study was the combination of both PO and LT vessels, which provided data suitable for density estimation. The longer time-span increased the probability of detecting all cetacean species and can be contrasted to large-scale surveys in which an area the size of the present study area is covered far less extensively, both in time and space. The timing of the LT survey unexpectedly supplied a 'peak' density for minke whales, whilst the PO datasets showed the temporal variability of the whales. The longer temporal coverage highlighted the problem of timing a dedicated survey properly and showed that PO vessels can successfully be used to identify areas and periods of high density to improve designs for future line-transect surveys.

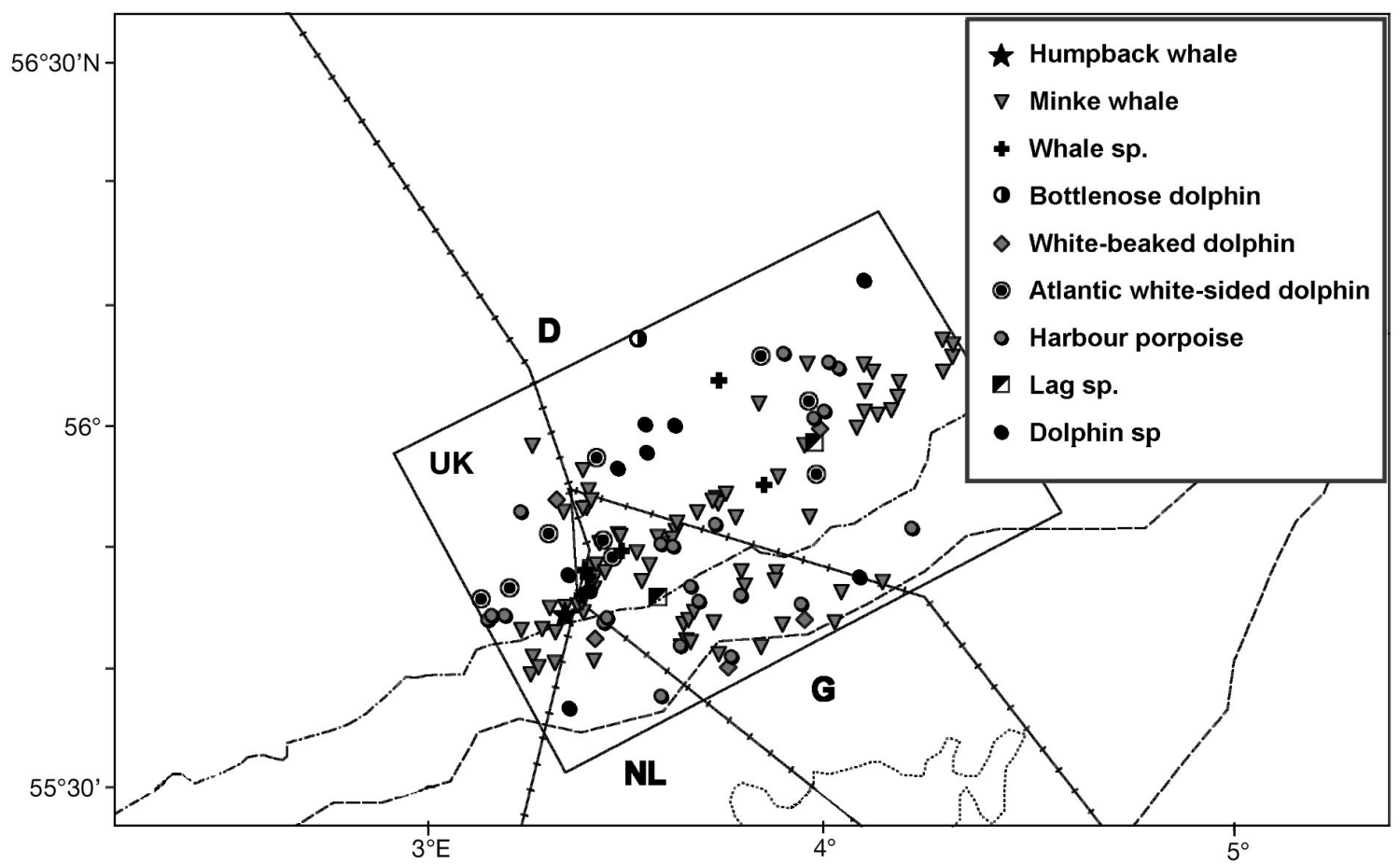

Fig. 5. The distribution of cetacean species in the study area from all vessels plotted by species. International EEZ waters (Denmark [D], United Kingdom [UK], The Netherlands [NL], and Germany [G]) and depth contours are shown: $50 \mathrm{~m}$ (dash-dot line), $40 \mathrm{~m}$ (dashed line) and $30 \mathrm{~m}$ (dotted line) 


\section{CONCLUSIONS}

Finding temporary congregation sites in offshore waters and identifying concentrations of animals requires a prolonged presence of observers, which is not easily achieved during standard surveys. To overcome the difficulties in detecting trends (e.g. expensive LT surveys) it will be important for future monitoring to apply a consistent methodology using suitable PO vessels. The present study showed the advantages of surveys at a finer spatial scale with longer temporal coverage and, as such, provided ecological information regarding foraging minke whales along an offshore bank in May.

At present there are some threats to minke whales in these waters, and an increased understanding of this species ecology is needed. Parts of the Dogger Bank have been proposed as SACs (sandbank habitat; Diesing et al. 2009). Our observations suggest that the slopes of the Dogger Bank support a high species diversity and offer a predictable foraging site for minke whales and other predators, particularly during spring when they exploit local sandeel aggregations. The habitat preferences of minke whales along this offshore bank appeared to be similar to those previously observed in coastal areas, and this suggests some degree of generality regarding the habitat preferences of minke whales in the north Atlantic. This offshore bank is currently the last extensive sandeel fishing ground in the North Sea, and concern has been raised regarding the effects of local sandeel depletion at the bank on their predators and the North Sea ecosystem as a whole (Mackinson 2007). Especially when prey becomes less abundant elsewhere, these offshore banks may become increasingly important to marine predators within the North Sea. It is necessary to further study the environmental variables in the area in order to predict the importance of these offshore banks as spring feeding habitats for minke whales and other top predators.

Acknowledgements. I thank all vessel personnel and observers who helped with the observations. In particular I thank the crew of the MV 'Thor Provider'. Thanks also to M. Baines who prepared the survey design; to Wintershall, PGS, and their partners who sponsored this study; and to H. Van den Berge who shared her enthusiasm and was integral to the success of this project. The manuscript was improved by comments from M. Leopold, M. Scheidat, G. Aarts, and 4 anonymous reviewers.

\section{LITERATURE CITED}

Barlow J, Forney KA (2007) Abundance and population density of cetaceans in the California Current ecosystem. Fish Bull 105:509-526

Boulcott P, Wright PJ, Gibb FM, Jensen H, Gibb IM (2006)
Regional variation in maturation of sandeels in the North Sea. ICES J Mar Sci 64:369-376

Buckland ST, Anderson DR, Burnham KP, Laake JL, Borchers DL, Thomas L (2001) Introduction to distance sampling: estimating abundance of biological populations. Oxford University Press, New York, NY

Camphuysen CJ (2004) The return of the harbour porpoise (Phocoena phocoena) in Dutch coastal waters. Lutra 47: 135-144

Camphuysen CJ (2007) Foraging humpback whale (Megaptera novaengliae) in the Marsdiep area (Wadden Sea), May 2007 and a review of sightings and strandings in the southern North Sea, 2003-2007. Lutra 50:31-42

Camphuysen CJ, Scott BE, Wanless S (2006) Distribution and foraging interactions of seabirds and marine mammals in the North Sea: multi-species foraging assemblages and habitat-specific feeding strategies. In: Boyd IL, Wanless S, Camphuysen CJ (eds) Top predators in marine ecosystems. Cambridge University Press, Cambridge, p 82-97

Certain G, Ridoux V, Van Canneyt O, Bretagnolle V (2008) Delphinid spatial distribution and abundance estimates over the shelf of the Bay of Biscay. ICES J Mar Sci 65: 656-666

de Boer MN, Leaper R, Keith S, Simmonds M (2008) Winter abundance estimates for the common dolphin (Delphinus delphis) in the western approaches of the English Channel and the effect of responsive movement. J Mar Anim Ecol $1: 14-20$

Diesing M, Ware S, Foster-Smith B, Stewart H and others (2009) Understanding the marine environment - seabed habitat investigations of the Dogger Bank offshore draft SAC, Joint Nature Conservation Committee Report 429, JNCC, Peterborough

Edwards M, Richardson AJ (2004) Impact of climate change on marine pelagic phenology and trophic mismatch. Nature 430:881-884

Evans PGH, Anderwald P, Baines ME (2003) UK Cetacean Status Review. Report to English Nature \& Countryside Council for Wales. Sea Watch Foundation, New Quay

Folkow LP, Haug T, Nilssen KT, Nordoy ES (2000) Estimated food consumption of minke whales Balaenoptera acutorostrata in northeast Atlantic waters in 1992-1995. In: Víkingsson GA (ed) Minke whales, harp and hooded seals: major predators in the North Atlantic ecosystem. The North Atlantic Marine Mammal Commission (NAMMCO) scientific publications 2:65-81

Gilles A, Scheidat M, Siebert U (2009) Seasonal distribution of harbour porpoises and possible interference of offshore wind farms in the German North Sea. Mar Ecol Prog Ser 383:295-307

Hammond P, Benke H, Berggren P, Borchers DL and others (1995) Distribution and abundance of the harbour porpoise (Phocoena phocoena) and other small cetaceans in the North Sea and adjacent waters. LIFE-92-2/UK/027 Report, SMRU, Gatty Marine Laboratory, University of St Andrews

Hammond PS, Berggren P, Benke H, Borchers DL and others (2002) Abundance of harbour porpoises and other cetaceans in the North Sea and adjacent waters. J Appl Ecol 39:361-376

ICES (International Council for the Exploration of the Sea) (2008a) Sandeel in subarea IV. Book 6, Chap 4.24. ICES, Copenhagen, p 15-25

ICES (2008b) An assessment of the changes in the distribution and abundance of marine species in the OSPAR maritime area in relation to changes in hydrodynamics and sea temperature. Book 1. ICES, Copenhagen, p 22-60

Johnston DW, Thorne LH, Read AJ (2005) Fin whales Bal- 
aenoptera physalus and minke whales B. acutorostrata exploit a tidally driven island wake ecosystem in the Bay of Fundy. Mar Ecol Prog Ser 305:287-295

Joint Nature Conservation Committee (2004). Guidelines for minimising acoustic disturbance to marine mammals, Joint Nature Conservation Committee, Peterborough

Knijn RJ, Boob TW, Heessen HJL, Hislop JRG (1993) Atlas of North Sea fishes. ICES Research Report 194, ICES Copenhagen

Laidre KL, Heagerty PJ, Heide-Jørgensen MP, Witting L, Simon M (2009) Sexual segregation of minke whales (Balaenoptera acutorostrata) in Greenland. ICES J Mar Sci 66: $2253-2266$

Lindeboom H, Van Kessel J, Berkenbosch L (2005) Areas with special ecological values on the Dutch Continental Shelf. Report 2005.008/1203, Alterra/RIKZ, Texel

Macer CT (1966) Sandeels (Ammodytidae) in the southern North Sea. J Mar Biol Assoc UK 45:187-207

Mackinson S (2007) Multi-species fisheries management: a comprehensive impact assessment of the sandeel fishery along the English east coast. CEFAS report for DEFRA, DEFRA, London

Macleod K, Fairbairns R, Gill A, Fairbairns B, Gordon J, BlairMyers C, Parsons ECM (2004) Seasonal distribution of minke whales Balaenoptera acutorostrata in relation to physiography and prey off the Isle of Mull, Scotland. Mar Ecol Prog Ser 277:263-274

MacLeod CD, Bannon SM, Brereton T, Wall D (2007) Using passenger ferries to study seasonal patterns of minke whale occurrence in NW Europe. In: Robinson KP, Stevick TP, MacLeod CD (eds) An integrated approach to nonlethal research on minke whales in European waters. European Cetacean Society (ECS)-Special 47, ECS, San Sebastian, p 32-37

> Marques FFC, Buckland ST (2003) Incorporating covariates into standard line transect analyses. Biometrics 59: 924-935

> Naud MJ, Lonf B, Brêthes JC (2003) Influences of underwater bottom topography and geomorphology on minke whale (Balaenoptera acutorostrata) distribution in the Mingan Islands. J Mar Biol Assoc UK 83:889-896

> Nielsen Gissel T, Munk P (1998) Zooplankton diversity and the predatory impact by larval and small juvenile fish at the Fisher Banks in the North Sea. J Plankton Res 20: 2313-2332

Northridge SP, Tasker ML, Webb A, Williams JM (1995) Distribution and relative abundance of harbour porpoises (Phocoena phocoena), white-beaked dolphins (Lagenorhynchus albirostris), and minke whales (Balaenoptera acutorostrata) around the British Isles. ICES J Mar Sci 52: 55-66

Olsen E, Holst JC (2001) A note on common minke whale (Balaenoptera acutorostrata) diets in the Norwegian Sea and the North Sea. J Cetacean Res Manag 3:179-183

Palka D (2005) Shipboard surveys in the Northwest Atlantic: estimation of $g_{(0)}$. In: Thomson F, Ugarte F, Evans PGH (eds) Estimation of $g_{(0)}$ in line-transect surveys of cetaceans. European Cetacean Society (ECS) Special, 44, ECS, San Sebastian, p 33-39

> Pierce GJ, Santos MB, Reid RJ, Patterson IAP, Ross HM (2004) Diet of minke whales (Balaenoptera acutorostrata) in Scottish (UK) waters with notes on strandings of this species in Scotland 1992-2002. J Mar Biol Assoc UK 84: 1241-1244

Pingree RD, Griffiths DK (1978) Fronts on the shelf seas around the British Isles. J Geophys Res 83:4615-4622

Reid JB, Evans PGH, Northridge SP (2003) Atlas of cetacean distribution in northwest European waters. Joint Nature Conservation Committee, Peterborough
Riegman R, Colijn F (1991) Evaluation of measurements and calculation of primary production in the Dogger Bank area (North Sea) in summer 1988. Mar Ecol Prog Ser 69: 125-132

Robinson KP, Baumgartner N, Eisfeld SM, Clark NM and others (2007) The summer distribution and occurrence of cetaceans in the coastal waters of the outer southern Moray Firth in northeast Scotland (UK). Lutra 50:19-30

$>$ Robinson KP, Tetley MJ, Mitchelson-Jacob EG (2009) The distribution and habitat preference of coastally occurring minke whales (Balaenoptera acutorostrata) in the outer Moray Firth, northeast Scotland. J Coast Conserv 13:39-48

Santos MB, Pierce GJ, Learmonth JA, Reid RJ and others (2004) Variability in the diet of harbour porpoises (Phocoena phocoena) in Scottish waters 1992-2003. Mar Mamm Sci 20:1-27

Small Cetaceans in the European Atlantic and North Sea (SCANS-II) (2008) Final report submitted to the European Commission, LIFE-04NAT/GB/000245 Report, SMRU, Gatty Marine Laboratory, University of St Andrews

> Schweder T, Skaug HT, Langaas M, Dimakos X (1999) Simulated likelihood methods for complex double-platform line transect surveys. Biometrics 55:678-687

Skaug H, Schweder T (1999) Hazard models for line transect surveys with independent observers. Biometrics 55:29-36

> Skaug HJ, Óien N, Schweder T, Bothun G (2004) Abundance of minke whales (Balaenoptera acutorostrata) in the northeast Atlantic: variability in time and space. Can J Fish Aquat Sci 61:870-886

> Stockin KA, Fairbairns RS, Parsons ECM, Sims DW (2001) Effects of diel and seasonal cycles on the dive duration of the minke whale (Balaenoptera acutorostrata). J Mar Biol Assoc UK 81:189-190

Stone CJ, Webb A, Barton C, Ratcliffe N and others (1995) Atlas of seabird distribution in north-west European waters. Joint Nature Conservation Committee, Peterborough

Tetley MJ, Mitchelson-Jacob EG, Robinson KP (2008) Summer distribution of coastal minke whales (Balaenoptera acutorostrata) in the southern outer Moray Firth, NE Scotland, in relation to co-occurring mesoscale oceanographic features. Remote Sens Environ 112:3449-3454

Todd VLG, Pearse WD, Tregenza NC, Lepper PA, Todd IB (2009) Diel echolocation activity of harbour porpoises (Phocoena phocoena) around North Sea offshore gas installations. ICES J Mar Sci 66:734-745

> Van der Kooij J, Scott BE, Mackinson S (2008) The effects of environmental factors on daytime sandeel distribution and abundance on the Dogger Bank. J Sea Res 60:201-209

Van der Meij SET, Camphuysen CJ (2006) The distribution and diversity of whales and dolphins (Cetacea) in the southern North Sea: 1970-2005. Lutra 49:3-28

Van Haren JJM, Joordens JCA (1990) Observations on physical and biological parameters at the transition between the southern and central North Sea. Neth J Sea Res 25: 351-364

Weir CR, Stockin KA, Pierce GJ (2007) Spatial and temporal trends in the distribution of harbour porpoises, whitebeaked dolphins and minke whales off Aberdeenshire (UK), north-western North Sea. Mar Biol Assoc UK 87 : 327-338

- Winslade P (1974) Behavioural studies on the lesser sandeel Ammodytes marinus: the effect of light intensity on activity. J Fish Biol 6:577-586

> Zerbini AN, Waite JM, Laake JL, Wade PR (2006) Abundance, trends and distribution of baleen whales off western Alaska and the central Aleutian Islands. Deep-Sea Res I 53:1772-1790

Submitted: September 29, 2009; Accepted: March 24, 2010

Proofs received from author(s): May 20, 2010 